\title{
Behavioural and biochemical responses of two marine invertebrates Scrobicularia plana and Hediste diversicolor to copper oxide nanoparticles
}

\author{
Pierre-Emmanuel Buffet ${ }^{\mathrm{a}, \mathrm{b}}$, Olivia Fossi Tankoua ${ }^{\mathrm{a}}$, Jin-Fen Pan ${ }^{\mathrm{a}, \mathrm{g}}$, Deborah Berhanuc, \\ Christine Herrenknecht ${ }^{a}$, Laurence Poirier ${ }^{a}$, Claude Amiard-Triquet ${ }^{a}$, Jean-Claude Amiard ${ }^{a}$, \\ Jean-Baptiste Bérard ${ }^{d}$, Christine Risso ${ }^{e}$, Marielle Guibbolini ${ }^{e}$, Michèle Roméo ${ }^{e}$, Paul Reip ${ }^{f}$, \\ Eugenia Valsami-Jones ${ }^{c}$, Catherine Mouneyrac ${ }^{\mathrm{a}, \mathrm{b}, *}$
}

\footnotetext{
a Université de Nantes, MMS, EA2160, Faculté de pharmacie, 1 rue G. Veil, BP 53508, 44035 Nantes Cedex 1, France

${ }^{\mathrm{b}}$ Institut de Biologie et Ecologie Appliquée, CEREA, Université Catholique de l'Ouest, 44, rue Rabelais, 49008 Angers Cedex 01, France

${ }^{c}$ Department of Mineralogy, Natural History Museum, Cromwell Road, London, SW7 5BD, UK

d Laboratoire de Physiologie et Biotechnologie des Algues, IFREMER, BP 21105, 44311 Nantes Cedex 03, France

${ }^{\mathrm{e}}$ Université de Nice-Sophia Antipolis, EA ECOMERS, Faculté des Sciences, Parc Valrose, BP 71, 06108 Nice, Cedex 2, France

${ }^{\mathrm{f}}$ Intrinsiq Materials Limited, Y25 Cody Technology Park, Farnborough, GO14 OLX, UK

${ }^{\mathrm{g}}$ College of Environmental Science and Engineering, Ocean University of China, China
}

\author{
*: Corresponding author : Catherine Mouneyrac, Tel.: +33 241816645 ; fax: +33 241816674 ; \\ email address : catherine.mouneyrac@uco.fr
}

\begin{abstract}
:
Engineered nano-sized $\mathrm{Cu}$ oxide particles are extensively used in diverse applications. Because aquatic environments are the ultimate "sink" for all contaminants, it is expected that nanoparticles (NP) will follow the same fate. In this study, two marine invertebrates Scrobicularia plana and Hediste diversicolor were chosen as ecotoxicological models. The aim was to evaluate behavioural (burrowing kinetics, feeding rate) and biochemical (biomarkers) responses of $S$. plana and $H$. diversicolor exposed in the laboratory to $\mathrm{Cu}\left(10 \mu \mathrm{L}^{-1}\right)$ added in natural seawater either in the form of engineered nanoparticles (NPs) of $\mathrm{CuO}$ or as dissolved $\mathrm{Cu}$ in $2 \% \mathrm{HNO}_{3}$. Exposure was characterized by considering (i) the physico-chemical fate of NP (ii) the fraction of labile $\mathrm{Cu}$ in experimental media and (iii) $\mathrm{Cu}$ bioaccumulation. Results showed high aggregation of $\mathrm{CuO}$ NPs in seawater and no additional bioavailable $\mathrm{Cu}$ concentrations. Behavioural impairments were observed in $\mathrm{S}$. plana exposed to $\mathrm{CuO}$ $\mathrm{NPs}$ or soluble $\mathrm{Cu}$ whereas in $\mathrm{H}$. diversicolor, only the exposure to soluble $\mathrm{Cu}$ led to a burrowing decrease. No obvious neurotoxicity effects were revealed since in both species, no changes in cholinesterasic activity occurred in response to both forms of $\mathrm{Cu}$ exposure. Biomarkers of oxidativestress catalase and glutathione-S-transferase were enhanced in both species whereas superoxide dismutase was increased only in S. plana exposed to $\mathrm{CuO}$ NPs. Metallothionein-like protein was increased in bivalves exposed to both forms of $\mathrm{Cu}$. Since, no detectable release of soluble $\mathrm{Cu}$ from
\end{abstract}


CuO NPs occurred during the time of experiment, ecotoxicity effects seem to be related to CuO NPs themselves.

\section{Research highlights}

Assessment of ecotoxicity of CuO NP which are extensively used in many applications. Biological models are target species for NPs mainly associated with sediment. Laboratory tests were carried out with environmentally realistic doses of copper. Comparison of ecotoxicity of copper either in solution or as nanoparticles. Determination of defence biomarkers able to prevent damages (mainly oxidative stress).

Keywords : Copper oxide nanoparticles ; Behaviour ; Biomarkers ; Oxidative stress ; Scrobicularia plana; Hediste diversicolor 


\section{Introduction}

Because the physicochemical properties of nanoparticles are distinct from their bulk counterparts, the fast growth of nanotechnologies has brought new industrial and business opportunities. For instance, engineered nano-sized copper oxide particles (CuO NP) are commonly used as bacteriocides and have the potential to replace noble metal catalysts for carbon monoxide oxidation (Zhou et al., 2006). CuO NP suspensions (nanofluids) have excellent thermal conductivity and are used as a heat transfer fluid in machine tools (Chang et al., 2005). Health and environmental concerns on free engineered nanoparticles (ENPs) have been highlighted in several reports (European Commission, 2009; Royal Commission on Environmental Pollution, 2008). Because aquatic environments are the ultimate "sink" for all contaminants, it is expected that ENPs will follow the same fate (Kaegi et al., 2008). Environmental monitoring data of engineered NPs, arising from use in consumer products, are currently lacking, which could be due to the difficulty to detect and quantify ENPs in complex matrices, such as water, sediments, and soils, as well as in organisms and their susceptible tissues (Wiesner et al., 2006; Nowack and Bucheli, 2007). Most of the ecotoxicological studies published are conducted with high NP concentrations, probably unrealistic from an environmental point of view as indicated by Predicted Environmental Concentrations of ENPs arising from use in consumer products (Tiede et al., 2009).

In order to investigate putative ecological impairments caused by ENPs, it is necessary to select species which have a key role in the structure and functioning of ecosystems and are recognized as good models for biomonitoring purposes. In this way, marine invertebrates such as the ragworm Nereis diversicolor and the bivalve mollusc Scrobicularia plana (Byrne and Halloran, 2001; Solé et al., 2009) represent good candidates. Soluble forms of copper are highly toxic in aquatic organisms (Eisler, 2007; Luoma and Rainbow, 2008). In the case of Cu-containing NPs, the release of $\mathrm{Cu}$ and its speciation may be a key factor in their ecotoxicity, besides that related to the nanoparticle itself. Biomarkers of defence (Metallothionein: MT, Catalase: CAT, glutathione-S-transferase: GST, superoxide dismutase: SOD) and damage (thibarbyturic acid reactive substances: TBARS, acetylcholinesterase: AChE) are commonly used in environmental assessment (Lagadic et al., 2000; Amiard and Amiard-Triquet, 2008). Lactate dehydrogenase (LDH) activity, as the terminal enzyme of anaerobic glycolysis, plays an important function in anaerobic metabolism (Gagnon and Holdway, 1999; Diamantino et al., 2001). In addition, behavioural biomarkers are sensitive tools to assess the impact of the contaminants at concentrations far below the lethal effect (Amiard-Triquet, 2009).

Nanoparticles of $\mathrm{CuO}$ were identified has being important in ecotoxicological assays due to its relatively low dissolution rate but its potentially high toxicity towards organisms (Stone et al. 2010). Thus, the aim of the present study was to evaluate biochemical and behavioural responses of two marine endobenthic invertebrates, Scrobicularia plana and Nereis diversicolor exposed in the laboratory to environmentally relevant $\mathrm{Cu}$ levels $\left(10 \mu \mathrm{g} \mathrm{L}^{-1}\right)$ added in natural filtered seawater either in the form of engineered $\mathrm{CuO}$ NP or as soluble $\mathrm{Cu}$. This Cu level $\left(10 \mu \mathrm{g} \mathrm{L}^{-1}\right)$ was reported in marine environments highly contaminated by this metal (Bryan and Langston, 1992). Exposure was characterized by considering the fate of NP (size distribution and fraction of labile $\mathrm{Cu}$ in experimental media) and $\mathrm{Cu}$ bioaccumulation. 


\section{Material and methods}

\subsection{Chemicals used and particle characterization}

$\mathrm{CuO}$ nanopowder was obtained from a commercial source (Intrinsiq Materials Limited) with the particle size specified by the manufacturer as 10-100 nm. A stock suspension of CuO nanoparticles $\left(25 \mathrm{mg} \mathrm{L}^{-1}\right)$ was prepared in deionized water (DIW), stored at $20^{\circ} \mathrm{C}$ and used for testing within two weeks. Before use, this stock suspension was sonicated for 5 minutes (Ultrasonicator BRANSON B-1200 E2 HF 100W). A stock solution of dissolved $\mathrm{Cu}$ as $\mathrm{CuNO}_{3}$ $\left(1 \mathrm{~g} \mathrm{Cu} \mathrm{L}^{-1}\right.$, in $\left.2 \% \mathrm{HNO}_{3} \mathrm{w} / \mathrm{w}\right)$ was purchased from Fluka Analytical. All the other chemicals were purchased from Sigma Aldrich.

The stability of CuO NP in both DIW (stock solution used within 2 weeks after preparation) and in the experimental medium (natural seawater) in the absence $(t=0)$ and presence $(t=2$ days) of organisms was monitored by dynamic light scattering (DLS). A suspension of CuO nanoparticles $\left(25 \mathrm{mg} \mathrm{L}^{-1}\right)$ in DIW was ultrasonicated for 10 s and the hydrodynamic diameter of the particles was measured using DLS (Malvern, Zetasizer Nano ZS). Then, $5 \mu$ of this stock solution were spiked into natural seawater $\left(10 \mu \mathrm{g} \cdot \mathrm{L}^{-1} \mathrm{Cu}\right.$ final concentration), and subsequently the size distribution and zeta potential of $\mathrm{CuO}$ nanoparticles were measured.

\subsection{Animal collection and acclimatation}

Worms ( $N$. diversicolor) and bivalves ( $S$. plana) were collected by hand from an intertidal mudflat (upper $20 \mathrm{~cm}$ depth) in the Bay of Bourgneuf ( $\left.2^{\circ} 04^{\prime} 40.60^{\prime \prime} \mathrm{W}, 46^{\circ} 56^{\prime} 23.08^{\prime \prime} \mathrm{N}\right)$, located on the West Atlantic coast (France), in July 2009. This site is monitored by the French "Mussel Watch" Programme (Réseau National d'Observation, 2006) and is documented as relatively clean (Kalman et al., 2009). Only bivalves with shell length ranging from 15 to $20 \mathrm{~mm}$ were selected to avoid any potential influence of sexual maturity. Worms from the same size were selected to avoid a potential influence of weight and they were collected in June which did not correspond to the period of sexual maturity (Mouneyrac et al 2010). Then, $N$. diversicolor and $S$. plana were transported to the laboratory in cool boxes with sediment from the collection site. In the laboratory, animals were allowed to eliminate their gut contents and acclimatize for $48 \mathrm{~h}$ in aerated natural seawater, UV treated and filtered through $0.45 \mu \mathrm{m}$.

\subsection{Exposure protocol}

We selected an aqueous medium because it was difficult to distribute evenly and reliably NPs in a natural sediment medium and both intra-sedimentary species studied (S. plana, $N$. diversicolor) were able to freely contact with NPs in the aqueous medium. Bivalves (S. plana) were placed into $2.2 \mathrm{~L}$ polypropylene aquaria (12 individuals/tank) filled with $2 \mathrm{~L}$ seawater and worms ( $N$. diversicolor) were introduced individually in plastic beakers of $100 \mathrm{~mL}$ filled

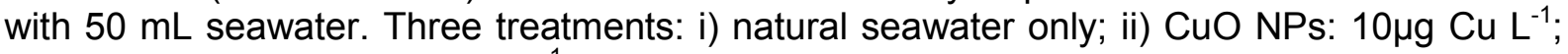
and iii) dissolved $\mathrm{Cu}: 10 \mu \mathrm{g} \mathrm{Cu} \mathrm{L}{ }^{-1}$, were carried out in a triplicate design during 16 days for $S$. plana and 7 days for $N$. diversicolor, using a semi-static exposure regime, in the dark at the temperature they experienced in their sediment of origin at this period of the year $\left(21^{\circ} \mathrm{C}\right)$. The experimental media (water and contaminant) were renewed every other day. 


\subsection{Metal quantification in experimental medium}

The estimation of dissolved bioavailable fraction of $\mathrm{Cu}$ was determined during Scrobicularia plana exposure in laboratory to seawater only (Controls), soluble $\mathrm{Cu}$ or $\mathrm{CuO} \mathrm{NP}$, by using DGT tools (diffusive gradients in thin films) (Davison and Zhang, 1994).

This technique, based on mass transport control of the chemical species of interest from water or sediment pores water, uses two hydrogel layers. A polyacrylamide gel is used as the diffusive layer, and is backed up with a second thin gel layer containing a Chelex cationexchange resin selective for trace metals. The diffusive layer of known thickness is placed in the DGT probe on top of the binding phase and covered with a filter used to avoid biofouling. lons diffuse through the filter and diffusive layer to reach the Chelex resin. The mass of the diffused ion, $M$, can be obtained by direct measurement of the ion concentration $\left(C_{r}\right)$ in the resin layer with total volume of resin $V_{r}$ :

$M=C_{r} V_{r}$

The DGT disc units $\left(2.5 \mathrm{~cm}\right.$ diameter corresponding to a $3.14 \mathrm{~cm}^{2}$ diffusive area) were purchased from DGT Research Ltd. A Chelex-100 resin beads and a diffusive gel with a pore size of about $5 \mathrm{~nm}$ were used (open pore diffusive gel) (Zhang and Davison, 1999). The thickness of gel was $0.82 \mathrm{~mm}$. A filter of $0.14 \mathrm{~mm}$ thickness and $0.45 \mu \mathrm{m}$ pores size covered the gel.

For each condition, 8 DGT units were deployed in the tanks containing Scrobicularia plana individuals and placed in temperature controlled room $\left(22^{\circ} \mathrm{C}\right)$. In order to avoid a bias due to the presence of DGT units in the medium, these individuals were not employed for biological tests.

Measurement of metal accumulated by the DGT units was realised on day $0,3,7$ and 16 (2 DGT per sampling day). After sampling, DGT units were washed with ultra-pure water (MilliQ) and placed in 1.5-mL vials. One milliliter of $1 \mathrm{M} \mathrm{HNO}_{3}$ was added and left for a day to elute copper from the Chelex resin. Copper determination was performed by graphite Furnace Atomic Absorption Spectrometry (Varian SpectrAA 800) in either neat or diluted samples of the $1 \mathrm{M} \mathrm{HNO}_{3}$ eluent. Mass of metal accumulated (M) by the DGT unit was calculated as follows:

$M=C_{r} V_{r}=C_{e}\left(V_{g}+V_{e}\right) / f_{e}$

Where $\mathrm{C}_{e}$ is the $\mathrm{Cu}$ concentration in $\mathrm{HNO}_{3}\left(\mu \mathrm{g} \cdot \mathrm{L}^{-1}\right), \mathrm{V}_{\mathrm{g}}$ and $\mathrm{V}_{\mathrm{e}}$, the volumes of the gel $\left(0.15 .10^{-3} L\right)$ and the eluent $\left(1.10^{-3} L\right)$ respectively and $f_{e}$, the elution factor $(0.8)$.

\subsection{Biochemical markers}

For each biomarker, 10 bivalves were collected from the three different tanks $(n=3$ or $n=4$ taken randomly from each tank) corresponding to each experimental condition. After exposure, the length and the total weight of bivalves were recorded. After removal of the shells, the soft tissues were carefully wiped with absorbent paper and stored at $-80^{\circ} \mathrm{C}$ until biochemical analysis. For worms, following exposure, they were carefully wiped with absorbent paper, weighed individually ( $\mathrm{n}=10$ for each biomarker) and stored at $-80^{\circ} \mathrm{C}$ until biochemical analysis. For MTLP and LDH, measurements were carried out individually. For GST, CAT, SOD, TBARS and AChE, determinations were carried out on 5 pools of 2 individuals of both species ( $N$. diversicolor, S. plana) per treatment. 
Because previous studies revealed that metallothionein-like protein (MTLP) determination was not a relevant biomarker of metal exposure in $N$. diversicolor (Poirier et al., 2006), MTLP analyses were performed only in bivalves (S. plana). The whole soft tissues of S. plana were homogenized at $4^{\circ} \mathrm{C}$ in $20 \mathrm{mM}$ TRIS, $10^{-5} \mathrm{mM} \quad \beta$-mercaptoethanol, $0.1 \mathrm{mM}$ Phenylmethanesulfonyl Fluoride (PMSF), $150 \mathrm{mM} \mathrm{NaCl}$ adjusted to $\mathrm{pH}=8.6\left(4 \mathrm{~mL} \mathrm{~g}^{-1} \mathrm{soft}\right.$ tissue). The soluble (S1) and insoluble (P1) fractions were separated by centrifugation at $30000 \mathrm{~g}$ for $30 \mathrm{~min}$ at $4^{\circ} \mathrm{C}$. An aliquot of the soluble fraction (S1) was heated at $75^{\circ} \mathrm{C}$ for 15 minutes. Then MTLPs (i.e. heat-stable thiolic compounds) were isolated by centrifugation (15000 $\mathrm{g}$ for 10 minutes at $4^{\circ} \mathrm{C}$ ) and determined by Differential Pulse Polarography (DPP) analysis (Mouneyrac et al., 2002). The standard addition method was used for calibration with rabbit liver MT (Sigma Chemical Co., St Louis, MO) in the absence of a marine bivalve MT standard.

For GST, CAT, SOD, TBARS and AChE, pooled soft tissues were homogenised at $4{ }^{\circ} \mathrm{C}$ to prevent enzyme or tissue degradation in TRIS buffer (TRIS $50 \mathrm{mM}, \mathrm{NaCl} 150 \mathrm{mM}$, DTT 1 $\mathrm{mM}$, antiprotease mixture (Sigma P8340, dilluted in 1/1000) adjusted to $\mathrm{pH} 7.4$ in a 1:3 ratio (w:v) using a motor-driven glass-Teflon homogenizer at $500 \mathrm{rpm}$. The homogenates were then centrifuged for $25 \mathrm{~min}$ at $9000 \mathrm{~g}$. Supernatants were immediately frozen at $-80^{\circ} \mathrm{C}$ as 50 $\mu \mathrm{L}$-aliquots until biomarker analysis. An aliquot of the homogenate was centrifuged $(9000 \mathrm{~g}$ for $30 \mathrm{~min}$ at $4^{\circ} \mathrm{C}$ ) and the resulting supernatant was used directly in the enzyme assay. GST activity was determined spectrophotometrically at $340 \mathrm{~nm}\left(\varepsilon=9.6 \mathrm{mM}^{-1} \mathrm{~cm}^{-1}\right)$ by monitoring the formation of 1-glutathion-2,4-dinitrobenzene, resulting from the conjugation of the substrate, 1-chloro-2,4-dinitrobenzene (CDNB), with glutathione reduced form (GSH), as described by Habig et al. (1974). Results were expressed as nmoles of glutathione conjugate produced per min and per mg protein (nmoles $\mathrm{min}^{-1} \mathrm{mg}^{-1}$ protein). CAT activity was estimated spectrophotometrically as the decrease in absorbance at $240 \mathrm{~nm}\left(\varepsilon=0.04 \mathrm{mM}^{-1} \mathrm{~cm}^{-1}\right)$ due to dismutation of hydrogen peroxide $\left(\mathrm{H}_{2} \mathrm{O}_{2}\right)$ according to Clairbone (1985). Results were expressed as $\mu$ moles of $\mathrm{H}_{2} \mathrm{O}_{2}$ transformed per min and per mg protein ( $\mu$ moles $\mathrm{min}^{-1} \mathrm{mg}^{-1}$ protein). SOD activity was determined as the degree of inhibition of cytochromeC reduction by superoxide anion radicals generated by xanthine oxydase/xanthine reaction at $550 \mathrm{~nm}$ (McCord and Fridovitch, 1969). Results were expressed as SOD Unit per mg protein (SOD Unit $\mathrm{mg}^{-1}$ protein). One unit of SOD activity was defined as the amount of sample producing $50 \%$ inhibition in $1 \mathrm{~mL}$ reaction system per $\mathrm{mg}$ protein. AChE activity was determined using the method of Ellman et al. (1961) adapted to a microplate reader by Galgani and Bocquené (1991). Results were expressed as nmoles of thiocholine produced per min and per mg protein (nmoles $\mathrm{min}^{-1} \mathrm{mg}^{-1}$ protein). Lipid peroxidation was estimated by the formation of thiobarbituric acid reactive substances (TBARS), quantified by reference to MDA absorbance $\left(\varepsilon=1.56105 \mathrm{M}^{-1} \mathrm{~cm}^{-1}\right)$ at $530 \mathrm{~nm}$ (Halliwell and Gutteridge, 1985). Results were expressed as nmoles of TBARS produced per mg protein (nmoles of TBARS $\mathrm{mg}^{-1}$ protein).

For LDH determination, an aliquot of the homogenate prepared as described above for GST (but with individual specimens) was centrifuged at $3300 \mathrm{~g}$ for 5 minutes at $4^{\circ} \mathrm{C}$. Measurement of $\mathrm{LDH}$ activity was realized with a microplate reader as described in Diamantino et al. (2001). Proteins were quantified in the supernatants according to Bradford (1976).

\subsection{Metal quantification in animals}

For bivalves $\mathrm{Cu}$ was determined in the pellets and supernatants, the preparation of which has been described above for MTLP determination. Cu bioaccumulation was estimated in the whole soft tissues of worms ( $N$. diversicolor, $\mathrm{n}=9$ per condition). Animal tissues were digested by heating $\left(90^{\circ} \mathrm{C}\right)$ with Aqua Regia $\left(\mathrm{HCl} / \mathrm{HNO}_{3: 75 / 25)}\right.$ after preliminary tests showing that pure $\mathrm{HNO} 3$ was not sufficent to insure a complete dissolution of $\mathrm{Cu}$ from $\mathrm{CuO}$ $\mathrm{NP}$. Then, the quantification of $\mathrm{Cu}$ concentrations was performed by using Flame Atomic 
Absorption Spectrophotometry (FAAS, Varian SpectrAA800 spectrophotometer) with deuterium lamp background correction. Standard addition analyses were performed in an isomedium and added concentrations of Cu were $125 \mathrm{ng} \mathrm{mL}^{-1}, 250 \mathrm{ng} \mathrm{mL}^{-1}, 500 \mathrm{ng} \mathrm{mL}^{-1}$, $1000 \mathrm{ng} \mathrm{mL}^{-1}$. All labware were cleaned in $10 \%$ hydrochloric-acid bath for $24 \mathrm{~h}$ and rinsed three times with DIW before being used. The accuracy of the analyses was checked by digesting certified material (Mussel tissue, National Institute of Standards and Technology). In the case of bivalves, the total concentration was recalculated by adding concentrations of $\mathrm{Cu}$ in pellet and supernatant.

\subsection{Behavioural experiments}

For burrowing tests, 20 bivalves were collected from the three different tanks ( $n=6$ or $n=7$ taken randomly from each tank) corresponding to each experimental condition. For feeding tests all the bivalves were involved ( $n=36$ per condition distributed in three different tanks). Both burrowing and feeding tests were carried out with 20 ragworms per condition. At the end of the behavioural tests, animals were returned in their experimental medium of origin. This procedure is acceptable since Burlinson and Lawrence (2007) have shown that burrowing organisms were not affected by consecutive behavioural assays.

\subsubsection{Burrowing tests}

Bivalves ( $S$. plana) and worms ( $N$. diversicolor) were submitted to burrowing tests as described by Bonnard et al. (2009), after being previously exposed in the laboratory for 4 days to seawater only (controls), $\mathrm{CuO} \mathrm{NPs}$ or dissolved $\mathrm{Cu}$ as described in exposure protocol sub-section (see above). For bivalves ( $S$. plana), burrowing experiments were carried out in plastic containers filled with $3 \mathrm{~cm}$ of natural sediment (collected from sampling site) and topped up with $2 \mathrm{~L}$ of seawater. Natural sediment was homogenized by hand one day before experimentation. Burrowing behaviour was studied by placing individuals on the surface of the sediment and observing the number which had burrowed at frequent intervals; every 5 minutes in the $1^{\text {st }}$ hour, every 10 minutes in the $2^{\text {nd }}$ hour, every 20 minutes in the $3^{\text {rd }}$ and $4^{\text {th }}$ hour, then every hour until 6 or 7 hours of test. Twenty individuals of $N$. diversicolor were tested for each studied condition. Briefly, we used plastic clean containers of $100 \mathrm{~mL}$ filled with $5 \mathrm{~cm}$ of wet sediment from the site of origin. Twenty worms were placed individually on the sediment and their positions were recorded every two minutes during 30 minutes.

\subsubsection{Feeding rate}

The feeding rate was estimated for bivalves ( $S$. plana) and worms ( $N$. diversicolor) previously exposed for 11 or 7 days respectively, to seawater only (Controls), CuO NPs or soluble Cu. The feeding rate of $S$. plana was quantified according to the methodology described by Worrall and Widdows (1983) and adapted to our conditions. Algae Tetraselmis suecica supplied by IFREMER were used as food at a concentration of 10000 cell.mL $\mathrm{mL}^{-1}$ in each tank. The concentration of algae not ingested by bivalves was measured after 1 hour. The feeding rate of $N$. diversicolor was quantified according to the methodology described by Moreira et al. (2005). Twenty worms were fed 100 Artemia salina larvae into their individual plastic beakers containing $50 \mathrm{ml}$ of seawater. They were left undisturbed for $1 \mathrm{~h}$, then the remaining larvae were collected and counted and results were expressed as the number of larvae ingested per hour per individual. 


\subsection{Statistical analysis.}

The burrowing kinetic curves were In-transformed in order to linearize these data and then, they were compared by using analysis of covariance (ANCOVA) between regression coefficients of the least-square best-fit regression lines. Otherwise, results are presented as mean \pm SD. Significant differences were established by using one-way analysis of variance (ANOVA) or non-parametric Mann and Whitney comparison tests when variances of groups were different. Level of significance was established at $p \leq 0.05$. Statistical analyses were performed by using Xlstat pro 7.5.

\section{Results}

\subsection{Fate of $\mathrm{CuO}$ nanoparticles in the experimental medium}

Size distribution of CuO NP in DIW ranged from $40 \mathrm{~nm}$ to $500 \mathrm{~nm}$ (Figure $1 \mathrm{~A}$ ) and the prepared suspension was stable for approximately 1 month. When diluted in sea water (at both $\mathrm{t}=0$ and $\mathrm{t}=2$ days where animal stayed during 2 days), the NPs aggregate/agglomerate and the sample is not suitable for DLS measurements. Figure $1 \mathrm{~B}$ shows how rapidly the size of the particles increases when $5 \mu$ of sea water is added in the DIW suspension. Zeta potential measurements show that the particles are relatively highly positely charged (26.3 $\mathrm{mV}$ ) in DIW, which corroborates the stability of the suspension, while the NPs appear slightly negatively charged in seawater collected at $\mathrm{T}=0$ and $\mathrm{T}=2$ (-8.69 and $-7.72 \mathrm{mV}$ respectively), an indication of poor stability.

\section{2. $\mathrm{Cu}$ in the exposure medium}

Figure 2 shows the mass of copper accumulated by DGT units during the 16 days of laboratory exposure to seawater only (Controls), dissolved $\mathrm{Cu}$ or $\mathrm{CuO}$ NPs. The results obtained for DGT exposed to CuO nanoparticles, at a nominal concentration of $10 \mu \mathrm{g}$ of Cu. $\mathrm{L}^{-1}$, demonstrated that the masses of copper accumulated were similar to those accumulated by DGT units deployed in control tanks and significantly lower than those obtained with DGT units exposed to soluble copper (respectively on day 16: $0.338 \pm 0.012$ $\mu \mathrm{g} ; 0.383 \pm 0.055 \mu \mathrm{g}, 1.017 \pm 0.033 \mu \mathrm{g}$ ). This result indicates that no detectable liberation of labile copper from NPs occurred in the medium during the time of experiment.

\subsection{Cu bioaccumulation}

Cu concentrations in the whole soft tissues of $S$. plana, exposed in the laboratory during 16 days and $N$. diversicolor exposed during 7 days to seawater only (Controls), CuO NPs (10 $\mu \mathrm{g}$ $\left.\mathrm{Cu} \mathrm{L}{ }^{-1}\right)$ and soluble $\mathrm{Cu}\left(10 \mu \mathrm{Cu} \mathrm{L}^{-1}\right.$ in $1 \mathrm{M}$ of $\left.\mathrm{HNO}_{3}\right)$ are illustrated in Table 1. Bivalves (S. plana) and worms ( $N$. diversicolor) exposed to both forms of copper (CuO NPs and soluble $\mathrm{Cu}$ ) showed significantly higher concentrations compared to controls. In addition for both species, no significant differences were observed depending on the form of $\mathrm{Cu}$ in the exposure medium. 


\subsection{Biomarkers}

Measurements of biomarkers of defences and damages in bivalves ( $S$. plana) and worms ( $N$. diversicolor) are illustrated in Table 2. In both species exposed to CuO NPs, catalase and GST activities increased significantly compared to controls. In $N$. diversicolor, catalase activity also increased significantly after soluble $\mathrm{Cu}$ exposure treatments. In bivalves, SOD activity was significantly higher in animals exposed to CuO NP compared to controls or animals exposed to soluble $\mathrm{Cu}$. MTLP concentrations increased in bivalves exposed to both forms of copper (soluble $\mathrm{Cu}, \mathrm{CuO} \mathrm{NPs}$ ), but significantly only for soluble $\mathrm{Cu}$. For both species, no damages were observed according to the results of TBARS, LDH and AChE.

\subsection{Burrowing behaviour}

The burrowing behaviour of $S$. plana and $N$. diversicolor (previously exposed for 4 days to soluble $\mathrm{Cu}$, CuO NPs as well as controls) in sediment collected from their site of origin is shown in Figure $3 \mathrm{~A}$ and $\mathrm{B}$. Slopes and regression coefficients of the best-fit regression lines obtained after In transformation of the raw data are shown in Table 3 . In S. plana, the burrowing behaviour was significantly impaired in bivalves exposed to CuO NP or to soluble form of Cu compared to controls. In the case of $N$. diversicolor, only the exposure to soluble $\mathrm{Cu}$ led to a significant decrease of burrowing kinetics compared to controls and $\mathrm{CuO} N P$ exposure.

\subsection{Feeding rate}

Feeding rates of $S$. plana and $N$. diversicolor were exposed (controls, soluble $\mathrm{Cu}$, CuO NP) for 11 days or 7 days respectively. During the first hour of feeding, bivalves ( $S$. plana) in control medium showed the highest feeding rates $\left(6051 \pm 1003\right.$ cells $\left.\mathrm{h}^{-1}\right)$ while feeding rates were significantly impaired for specimens from CuO NP exposure medium (3680 \pm 1294 cells $\left.h^{-1}\right)$.

Concerning $N$. diversicolor feeding rates were not affected by experimental conditions (not shown).

\section{Discussion}

\subsection{Exposure}

The environmental fate and ecotoxicity of engineered NPs may be influenced by a number of properties, including particle size and size distribution, state of aggregation, charge and solubility. Following release to the environmental systems, most engineered NPs are able to aggregate to some degree. The degree and kinetics of aggregation and the size range of the aggregates is dependent on the characteristics of the particles, the characteristics of the environmental system, and the concentration of the nanopaticles. As aggregation is likely to affect toxicity, characterization of NP in experimental media is essential for nanoecotoxicology (Tiede et al., 2009). In the present study, the particle size of CuO NP specified by the manufacturer ranged from 10-100 nm. However, actual characterization of $\mathrm{CuO}$ NP in DIW showed that particle size ranged from $40 \mathrm{~nm}$ to $500 \mathrm{~nm}$ with an average of $197 \mathrm{~nm}$. In seawaters, the CuO NP highly aggregate/agglomerate and the hydrodynamic size (or Z-average) increased rapidly (Figure $1 \mathrm{~B}$ ) to values of around $1000 \mathrm{~nm}$ within the duration 
of the test. However, the aggregation/agglomeration of most NPs detected by DLS may not record the existence of some free NPs in the media, as previously expressed by Griffitt et al. (2008). The small size and the relatively large surface area of NP have been suggested to result in increased toxicity when compared to particles in the bulk form. In the case of metalcontaining NPs such as CuO NPs, the release of metal ions and their speciation may also be a key factor in their (eco)toxicity. The presence of organisms can affect particle dissolution in exposure medium (Griffitt et al., 2008). Thus, in this work, we studied the putative dissolution of $\mathrm{Cu}$ from $\mathrm{CuO}$ NP in real exposure (in the presence of animals) to estimate the contribution of dissolved $\mathrm{Cu}$ ions to overall cytotoxic effects. Solubility of copper oxide in water has been extensively studied under various $\mathrm{pH}$ and temperature conditions (Palmer et al., 2004). Models of bioavailability and of toxicity of copper ions have been proposed (Luoma and Rainbow, 2008). Since Zhang and Davison (1999) have described the DGT method, this has been widely used in environmental studies dealing with metal speciation in water (Pesavento et al., 2009). In the conditions of our experiment, DGT results indicated that no measurable release of labile $\mathrm{Cu}$ from $\mathrm{CuO}$ NPs occurred during the time of experiment (16 days). Griffitt et al. (2008) showed similar results, with less than $1 \%$ by mass of the original dose present in dissolved form after $48 \mathrm{~h}$ for copper in a freshwater medium. In contrast, Blinova et al. (2010) found, also in freshwater, higher copper dissolution (12\% of copper) from CuO NP using Escherichia coli Cu-sensor. This present work demonstrates the interest of using DGT techniques to estimate the bioavailability of metals released from NP under soluble form in the aquatic environment.

In addition, Solé et al. (2009) suggested that the different responses in the two sedimentdwelling organisms was attributable to different contamination exposures as they distinguished between the sediment-eating of the polychaete and the proposed water-filtering of the clam. However, the difference in their feeding habits is by no means so contrasted. On the contrary, Hughes (1969) describes $S$. plana primarily as a deposit-feeder, which obtains only some of its food by filtering suspended matter from the sea. $N$. diversicolor, as an opportunistic species, is considered able to fulfil its energy needs using different kinds of diet (Olivier et al. 1995).

\subsection{Cu bioaccumulation}

As documented earlier, both bivalves and worms exposed to soluble $\mathrm{Cu}$ in the experimental medium have incorporated $\mathrm{Cu}$. More interestingly, the concentrations reached in each species exposed to $\mathrm{Cu}$ as nanoparticles were identical to those due to soluble $\mathrm{Cu}$, despite DGT results did not indicate any measurable release of labile $\mathrm{Cu}$ from $\mathrm{CuO}$ NPs occuring during the time of experiment. However, NP can also be taken into the gut providing additional route for metal bioavailability. In a recent study, Galloway et al. (2010) using transmission electronic microscopy (TEM), observed that $\mathrm{TiO}_{2} \mathrm{NPs}$ were localized in the gut lumen in the marine polychaete Arenicola marina. Because we have seen that CuO NP was remarkably stable since pure HNO3 was insufficient to solubilized them (see subsection 2.6) it is less probable that they may be partially solubilized in the gut due to the moderate $\mathrm{pH}$ value in the gut of bivalves ( $\mathrm{pH}: 4$ to 5.2$)$ and worms ( $\mathrm{pH}: 5.5$ to 6).

\subsection{Ecotoxicity effects}

The fate and ecotoxicity of particles of nanometric size in endobenthic organisms such as the bivalve mollusc S. plana and the ragworm N. diversicolor is very poorly known. Questions appeared since recent studies showed that NP can be more toxic than their bulk form (Blinova et al., 2010; Heinlaan et al., 2008) or micrometric particles (Karlsson et al., 2009). It was previously shown that the toxicity of bulk and CuO NPs was due to the solubilized 
bioavailable fraction, most likely $\mathrm{Cu}^{2+}$ ions (Heinlaan et al., 2008). Since no additional labile $\mathrm{Cu}$ in seawater exposure media (compared to controls) was registered during the time of experiment (16 days), we have to investigate about the specific toxicity from nanoparticulate copper.

Induction of MT, a cystein-rich protein that binds metals and thus contributes to metal detoxification, has been reported in various aquatic species under in situ or laboratory metals exposure (Amiard et al., 2006). Significantly higher MTLP levels and concomitantly higher soluble $\mathrm{Cu}$ concentrations in S. plana exposed to soluble $\mathrm{Cu}$ compared to controls reinforced the homeostatic and detoxification functions of this metal-binding protein in bivalves. The precise mechanisms of toxicity for NP are largely unknown. Our results showed that CuO NP are able to induce impairments in both studied species. Several studies reported that nanoparticles contribute to oxidative stress (Unfried et al., 2007). In this work, an increase (not significant) of MTLP was observed in bivalves exposed to CuO NP independently of $\mathrm{Cu}$ bioaccumulation in the soluble fraction. Thus, MTLP in S. plana could be involved in the defence against oxidative stress as described previously in the mussel Mytilus galloprovincialis (Viarengo et al., 1999) and not involved directly in the detoxification of CuO NPs. CAT, GST and SOD have been classified as antioxidant systems of defence in various aquatic species such as bivalves (Almeida et al., 2007). CAT and GST activities increased significantly in both species (S. plana, N. diversicolor) and SOD in S. plana exposed to CuO $\mathrm{NP}$, suggesting an oxidative stress endured by animals.

Concerning biomarkers of damages, no alteration of TBARS levels, LDH and AChE activities were depicted in any cases and in both species, under the experimental conditions. It may be suggested that the antioxidant defences could play their role by preventing oxidative damage. However, defence mechanisms were probably not sufficient to prevent behavioural impairments. Burrowing kinetics were significantly impaired in S. plana exposed to both forms of $\mathrm{Cu}(\mathrm{CuO} \mathrm{NP}$ or soluble $\mathrm{Cu}$ ) compared to controls whereas for feeding rate only in the case of $\mathrm{CuO}$ NP exposure. In the case of $\mathrm{N}$. diversicolor, only the exposure to soluble $\mathrm{Cu}$ led to a significant decrease of the burrowing kinetic of worms and feeding rate seemed not to be affected by experimental conditions. In a similar way, Wallace et al. (2000) showed that saturation of Cd-MT in grass shrimp fed cadmium-contaminated preys was associated with decreased the prey capture.

In invertebrates, tolerance to environmental contaminants is based upon a large range of chemical handling strategies. So it is not surprising that responses differ between a bivalve and a polychaete. In the case of toxic metals but also essential metals in large excess, a first line of defence is based on MT as a detoxificatory ligand. Previous works have wellestablished that the way MT plays a protective role is different between these taxa. The concentration of this metalloprotein is generally increased in bivalves exposed to metal pollution, providing directly a detoxificatory ligand (Amiard et al., 2006) whereas in certain polychaete species, it is MT turnover which is substantially increased in response to metal exposure, probably allowing the transfer from cytosol to detoxificatory granules ( $\mathrm{Ng}$ et al., 2008). In N. diversicolor originating from highly $\mathrm{Cu}$ contaminated site, $\mathrm{Cu}$ granules were observed as a major sink for bioaccumulated Cu (Mouneyrac et al. 2003).

Links between behavioural impairment and AChE inhibition is well-documented for aquatic biota (Amiard-Triquet, 2009). In the present study, behavioural impairments were not accompanied by an inhibition of AChE activity, but metabolical or physiological disturbances due to the "cost of tolerance" could be the cause of these impairments (Bonnard et al., 2009). 


\section{Conclusions}

In conclusion, the $\mathrm{Cu}$ concentrations used in this study either in the form of CuO NPs or soluble $\mathrm{Cu}$ are able to induce biological effects. It must be highlighted that the chosen soluble $\mathrm{Cu}$ concentrations of $10 \mu \mathrm{g} \mathrm{L}^{-1}$ may be encountered in polluted environments (since there is no available measured or predicited data on CuO NP concentrations) . Several biomarkers of defense are activated in the presence of CuO NPs, namely GST, CAT and SOD in Scrobicularia plana and CAT and GST in Nereis diversicolor. These defences may be relatively efficient since no significant effects were shown considering individually biochemical markers of damage. However, behavioural impairments were observed in the bivalve (S. plana), considering both the burrowing and feeding behaviours. For a number of biomarkers, it must be noted that biological responses are more important in the presence of $\mathrm{CuO}$ NPs than in the presence of soluble $\mathrm{Cu}$. Moreover, labile $\mathrm{Cu}$ quantity was lower in seawater contaminated by nanoparticles than soluble $\mathrm{Cu}$ at identical nominal concentrations $\left(10 \mu \mathrm{g} \mathrm{L}^{-1}\right)$. Thus, these results suggest a specific nanoparticle effect. Finally, the use of both marine invertebrates (S. plana, N. diversicolor) and the set of biomarkers chosen in this work seem suitable to conduct ecotoxicity studies with ENPs. With a view to risk assessment it is necessary to improve the evaluation of exposure and the subsequent bioaccumulation. Future works (TEM) are in progress to localize cellular targets of CuO NPs in both species.

\section{Acknowledgements}

The research leading to these results has received funding from the European Community's Seventh Framework Programme (FP7/2007-2013) under grant agreement $n^{\circ}$ [214478], project name NanoReTox. This work was supported by a scholarship from the Fondation Franco-Chinoise pour la Science et ses Applications (FFCSA) and the Région Pays de la Loire, France while the third author visiting the University of Nantes.

\section{References}

Adams, W. J.; Rowland, C. 1993. Aquatic toxicology test methods, in: Hoffman, D. J., Rattner, B. A., Burton, A.,Jr, Cairns J., Jr. (Eds.), Handbook of Ecotoxicology, CRC Press, Boca Raton, London New York, pp 18-38.

Almeida, E.A., Bainy, A.C.D., MeloLoureiro, A.P., Martinez, G.R., Miyamoto,S., Onuki, J., Barbosa, L.F., MachadoGarcia, C.C., Prado,F.M., Ronsein, G.E., Sigolo, C.A., Brochini,C.B., Martins, A.M.G., Medeiros, M.H.G., DiMascio, P., 2007. Oxidative stress in Perna perna and other bivalves as indicators of environmental stress in the Brazilian marine environment: Antioxidants, lipid peroxidation and DNA damage. Comp. Biochem. Physiol. A., 146 (4), 588600 .

Amiard-Triquet, C., 2009. Behavioral Disturbances: The Missing Link between SubOrganismal and Supra-Organismal Responses to Stress? Prospects Based on Aquatic Research. Hum. Ecol. Risk. Assess. 15 (1), 87 - 110.

Amiard, J., Amiard-Triquet, C., 2008. Les biomarqueurs dans l'évaluation de l'état écologique des milieux aquatiques, Lavoisier, Paris. 
Amiard, J. C., Amiard-Triquet, C., Barka, S., Pellerin, J., Rainbow, P. S., 2006. Metallothioneins in aquatic invertebrates: Their role in metal detoxification and their use as biomarkers. Aquat. Toxicol. 76 (2), 160-202.

Blinova, I., Ivask, A., Heinlaan, M., Mortimer, M., Kahru, A., 2010. Ecotoxicity of nanoparticles of $\mathrm{CuO}$ and $\mathrm{ZnO}$ in natural water. Environ. Pollut. 158 (1), 41-47.

Bonnard, M., Romeo, M., Amiard-Triquet, C., 2009. Effects of Copper on the Burrowing Behavior of Estuarine and Coastal Invertebrates, the Polychaete Nereis diversicolor and the Bivalve Scrobicularia plana. Hum. Ecol. Risk Assess. 15 (1), 11-26.

Bradford, M. M., 1976. A Rapid and Sensitive Method for the Quantitation of Microgram Quantities of Protein Utilizing the Principle of Protein-Dye Binding. Anal. Biochem., 72, 248254.

Bryan, G. W., Langston, W. J., 1992. Bioavailability, accumulation and effects of heavy metals in sediments with special reference to United Kingdom estuaries: a review. Environ. Pollut. 76 (2), 89-131.

Burlinson, F. C., Lawrence, A. J., 2007. A comparison of acute and chronic toxicity tests used to examine the temporal stability of a gradient in copper tolerance of Hediste diversicolor from the Fal estuary, Cornwall. UK. Mar. Pollut. Bull. 54 (1), 66-71.

Byrne, P. A., Halloran, J. O., 2001. The role of bivalve molluscs as tools in estuarine sediment toxicity testing: a review. Hydriobiologia. 465, 209-217.

Chang, H., Jwo, C., Lo, C., Tsung, T., Kao, M., Lin, H., 2005. Rheology of CuO nanoparticle suspension prepared by ASNSS. Rev. Adv. Mater. Sci. 10, 128-132.

Claiborne, A., 1985. Catalase activity, in Greenwald, R.A, (Ed.), Handbook of methods for oxygen radical research, CRC Press, Boca Raton London New York, pp 283-284.

Davison, W., Zhang, H., 1994. In situ speciation measurements of trace components in natural waters using thin-film gels. Nature 367, 545-548.

Diamantino, T. C., Almeida, E., Soares, A. M. V. M., Guilhermino, L., 2001. Lactate deshydrogenase activity as an effect criterion in toxicity tests with Daphnia magna straus. Chemosphère. 45, 553-560.

Eisler, R. 2007. Eisler's encyclopedia of environmentally hazardous priority chemicals. Elsevier Science Ltd, Oxford.

Ellman, G., Courtney, K., 1961. A new and rapid colorimetric determination of acetylcholinesterase activity. Bioch. pharmacol., 7 (2), 88-90.

European Commission. 2009. Nanosciences and Nanotechnologies: An action plan for Europe 2005-2009. Second Implementation Report 2007-2009. COM(2009)607 final, Brussels, 29.10.2009.

Gagnon, M. M., Holdway, D. A., 1999. Metabolic Enzyme Activities in Fish Gills as Biomarkers of Exposure to Petroleum Hydrocarbons. Ecotoxicol. Environ. Safety. 44 (1), 9299.

Galgani, F., Bocquene, G. 1991. Semi-automated colorimetric and enzymatic assays for aquatic organisms using microplate readers. Water Res., 25 (2), 147-150. 
Galloway, T., Lewis, C., Dolciotti, I., Johnston, B. D., Moger, J., Regoli, F. 2010. Sublethal toxicity of nano-titanium dioxide and carbon nanotubes in a sediment dwelling marine polychaete. Environ. Poll. 158 (5), 1748-1755.

Griffitt, R. J., Luo, J., Gao, J., Bonzongo, J. C., Barber, D. S., 2008. Effects of particle composition and species on toxicity of metallic nanomaterials in aquatic organisms. Environ. Toxicol. Chem. 27 (9), 1972-1978.

Habig, W., Pabst, M., Jakoby, W., 1974. Glutathione S-transferases. J. Biol. Chem. 249 (22), 7130-7139.

Halliwell, B., Gutteridge, J., 1985. Free radicals in biology and medicine Printed Resource. Oxford University Press, Oxford.

Heinlaan, M., Ivask, A., Blinova, I., Dubourguier, H.-C., Kahru, A., 2008. Toxicity of nanosized and bulk $\mathrm{ZnO}, \mathrm{CuO}$ and $\mathrm{TiO} 2$ to bacteria Vibrio fischeri and crustaceans Daphnia magna and Thamnocephalus platyurus. Chemosphere. 71 (7), 1308-1316.

Hughes, R. N., 1969. A study of feeding in Scrobicularia plana. J. Mar. Biol. Ass. U. K. 49, 805-823.

Kaegi, R., Ulrich, A., Sinnet, B., Vonbank, R., Wichser, A., Zuleeg, S., Simmler, H., Brunner, S., Vonmont, H., Burkhardt, M., Boller, M., 2008. Synthetic TiO2 nanoparticle emission from exterior facades into the aquatic environment. Environ. Poll. 156 (2), 233-239.

Kalman, J., Palais, F., Amiard, J., Mouneyrac, C., Muntz, A., Blasco, J., Riba, I., AmiardTriquet, C., 2009. Assessment of the health status of populations of the ragworm Nereis diversicolor using biomarkers at different levels of biological organisation. Mar. Ecol. Prog. Ser. 393, 55-67.

Karlsson, H. L., Gustafsson, J., Cronholm, P., Möller, L., 2009. Size-dependent toxicity of metal oxide particles: A comparison between nano- and micrometer size. Toxicol. Lett. 188 (2), 112-118.

Lagadic, L., Caquet, T., Amiard, J.-C., Ramade, F., 2000. Use of biomarkers for environmental quality assessment, first ed. CRC Press, USA.

Luoma, S., Rainbow, P. S., 2008. Metal contamination in aquatic environments: science and lateral management, Cambridge University Press. Cambridge.

McCord, J., Fridovich, I., 1969. An enzymatic function for erythrocuprein. J. Biol. Chem. 244, 6049-6055.

Moreira, S. M., Moreira-Santos, M., Guilhermino, L., Ribeiro R. A short-term sublethal in situ toxicity assay with hediste diversicolor (polychaeta) for estuarine sediments based on postexposure feeding. Environ. Tox. Chem 24 (8), 2010-2018.

Mouneyrac C., Amiard J.C., Amiard-Triquet C., Cottier A., Rainbow P. S., Smith B. D., 2002. Partitioning of accumulated trace metals in the talitrid amphipod crustacean Orchestia gammarellus: a cautionary tale on the use of metallothionein-like proteins as biomarkers. Aquatic Toxicology. 57 (4): 225-242. 
Mouneyrac, C., Mastain, O., Amiard, J. C., Amiard-Triquet, C., Beaunier, P., Jeantet, A.-Y., Smith, B. D., Rainbow, P. S., 2003. Trace-metal detoxification and tolerance of the estuarine worm Hediste diversicolor chronically exposed in their environment. Mar. Biol. 143, 731-744.

Mouneyrac, C., Perrein-Ettajani, H., Amiard-Triquet, C.. 2010 Influence of anthropogenic stress on fitness and behaviour of a key-species of estuarine ecosystems, the ragworm Nereis diversicolor Environ. Poll. 158 (1), 121-128.

Ng, T. Y. T., Rainbow, P. S., Amiard-Triquet, C., Amiard, J.-C., Wang, W.-X., 2008. Decoupling of cadmium biokinetics and metallothionein turnover in a marine polychaete after metal exposure. Aquat. Toxicol. 89 (1), 47-54.

Nowack, B., Bucheli, T. D., 2007. Occurrence, behavior and effects of nanoparticles in the environment. Environ. Poll. 150 (1), 5-22.

Olivier, M., Desrosiers, G., Caron, A., Retière, C., Caillou, A., 1995. Réponses comportementales des polychètes Nereis diversicolor (O.F. Müller) et Nereis virens (Sars) aux stimuli d'ordre alimentaire : utilisation de la matière organique particulaire (algues et halophytes). Can. J. Zool. 73 (12), 2307-2317.

Pesavento, M., Alberti, G., Biesuz, R., 2009. Analytical methods for determination of free metal ion concentration, labile species fraction and metal complexation capacity of environmental waters:A review. Anal. Chim. Acta. 631, 129-141.

Palmer, D. A., Bénézeth, P., Simonson, J. M., 2004. Solubility of Copper Oxides in Water and Steam, in: Nakahara, M., Matubayasi, N., Ueno, M., Yasuoka, K., Watanabe, K. (Eds.), Proceedings of the 14th International Conference in the Properties of Water and Steam, Kyoto, pp 491-496.

Poirier, L., Berthet, B., Amiard, J. C., Jeantet, A.-Y., Amiard-Triquet, C., 2006. A suitable model for the biomonitoring of trace metal bioavailabilities in estuarine sediments: the annelid polychaete Nereis diversicolor, J. Mar. Biol. Assoc. U.K. 86, 71-82.

RNO. French National Mussel Watch programme, Ifremer, Bulletin 2006. http://wwz.ifremer.fr/envlit/documents/bulletins/rno.

Royal Commission on Environmental Pollution 2008. Novel Materials in the Environment: The case of nanotechnology. Twenty ninth report.

Solé, M., Kopecka-Pilarczyk, J., Blasco, J., 2009. Pollution biomarkers in two estuarine invertebrates, Nereis diversicolor and Scrobicularia plana, from a Marsh ecosystem in SW Spain. Environ. Int. 35 (3), 523-531.

Stone, V., Nowack B., Baun A., van den Brink, N., Kammer, F., Dusinska, M., Handy, R., Hankin, S., Hassellöv, M., Joner, E., Fernandes, TF., 2010. Nanomaterials for environmental studies: classification, reference material issues, and strategies for physico-chemical characterisation. Sci Total Environ. 408 (7), 1745-54.

Tiede, K., Tear, S. P., David, H., Boxall, A. B., A. 2009. Imaging of engineered nanoparticles and their aggregates under fully liquid conditions in environmental matrices. Water Res. 43 (13), 3335-3343.

Unfried, K., Albrecht, C., Klotz, L.-O., Von Mikecz, A., Grether-Beck, S., Schins, R. P. F., 2007. Cellular responses to nanoparticles: Target structures and mechanisms. Nanotoxicology. 1 (1), 52-71. 
Viarengo, A., Burlando, B., Cavaletto, M., Marchi, B., Ponzano, E., Blasco, J., 1999. Role of metallothionein against oxidative stress in the mussel Mytilus galloprovincialis. Am. J. Physiol. Regul. Integr. Comp. Physiol. 277 (6), 1612-1619.

Wallace, W. G., Brouwer, T.M.H, Brouwer, M., Lopez, G.R., 2000. Alterations in prey capture and induction of metallothioneins in grass shrimp fed cadmium-contaminated prey Environ. Toxicol. Chem. 19 (4), 962-971.

Wiesner, M. R., Lowry, G. V., Alvarez, P., Dionysiou, D., Biswas, P., 2006. Assessing the Risks of Manufactured Nanomaterials. Environ. Sci. Technol. 40 (14), 4336-4345.

Worrall, C. M., Widdows, J., 1983. Physiological changes following transplantation of the bivalve Scrobicularia plana between three populations. Mar. Ecol. prog. Ser. 12, 281-287.

Zhang, H., Davison, W., 1999. Diffusional characteristics of hydrogels used in DGT and DET techniques. Anal. Chim. Acta. 398 (2-3), 329-340.

Zhou, K., Wang, R., Xu, B., Li, Y., 2006. Synthesis, characterization and catalytic properties of $\mathrm{CuO}$ nanocrystals with various shapes. Nanotechnology, 17 (15), 3939-3943.

\section{Tables}

Table 1. Mean (ng g ${ }^{-1}$ wet weight) copper concentrations (and SD between brackets) in Scrobicularia plana and in Nereis diversicolor (whole soft tissues) exposed in the laboratory to $\mathrm{Cu}\left(10 \mu \mathrm{g} \mathrm{L}^{-1}\right)$ either in the form of $\mathrm{CuO} \mathrm{NP}(\mathrm{CuO} \mathrm{NP})$, soluble $\mathrm{Cu}$ and seawater only (Controls). Concentrations with different superscripts differed significantly at the $95 \%$ level in each species.

\begin{tabular}{|l|l|l|}
\hline & S. plana & N. diversicolor \\
\hline Controls & $3634(1915)^{\mathrm{a}}$ & $1006(132)^{\mathrm{c}}$ \\
\hline Soluble Cu & $5998(3023)^{\mathrm{b}}$ & $1431{\left(\text { (583) }^{\mathrm{d}}\right.}^{\mathrm{d}}$ \\
\hline CuO NP & $7495(2379)^{\mathrm{b}}$ & $1570(302)^{\mathrm{d}}$ \\
\hline
\end{tabular}


Table 2. Means (and SD between brackets) of biomarkers quantified in Nereis diversicolor after $7 \mathrm{~d}$ and Scrobicularia plana after $16 \mathrm{~d}$ of exposure treatments (Controls, soluble $\mathrm{Cu}$, $\mathrm{CuO}$ NP). For both species, biomarker levels with different superscripts differed significantly at the $95 \%$.

\begin{tabular}{|c|c|c|c|c|c|c|c|}
\hline \multicolumn{2}{|l|}{ Biomarkers } & \multicolumn{3}{|c|}{ Scrobicularia plana } & \multicolumn{3}{|c|}{ Nereis diversicolor } \\
\hline & & $\begin{array}{l}\text { Controls } \\
(n=5)\end{array}$ & $\begin{array}{l}\text { Soluble } \mathrm{Cu} \\
\left(10 \mu \mathrm{g} \mathrm{L}^{-1}\right) \\
(n=5)\end{array}$ & $\begin{array}{l}\text { CuO NP } \\
\left(10 \mu \mathrm{g} \mathrm{L}^{-1}\right) \\
(n=5)\end{array}$ & $\begin{array}{l}\text { Controls } \\
(n=5)\end{array}$ & $\begin{array}{l}\text { Soluble } \mathrm{Cu} \\
\left(10 \mu \mathrm{g} \mathrm{L}^{-1}\right) \\
(n=5)\end{array}$ & $\begin{array}{l}\text { CUO NP } \\
\left(10 \mu \mathrm{g} \mathrm{L}^{-1}\right) \\
(n=5)\end{array}$ \\
\hline \multirow[t]{5}{*}{ Defences } & $\begin{array}{l}\text { CAT } \\
\left(\mu \mathrm{mol} \mathrm{min}^{-1} \mathrm{mg}^{-1}\right. \\
\text { protein) }\end{array}$ & $\begin{array}{l}66.50 \\
(16.59)^{\mathrm{a}}\end{array}$ & $80.98(3.53)^{a}$ & $\begin{array}{l}119.35 \\
(17.70)^{b}\end{array}$ & $\begin{array}{l}53.27 \\
(2.46)^{\mathrm{a}}\end{array}$ & $78.05(9.35)^{b}$ & $\begin{array}{l}96.51 \\
(13.45)^{c}\end{array}$ \\
\hline & $\begin{array}{l}\text { GST } \\
\text { (nmol min }{ }^{-1} \mathrm{mg}^{-1} \\
\text { protein) }\end{array}$ & $\begin{array}{l}260.87 \\
(43.68)^{a}\end{array}$ & $\begin{array}{l}311.40 \\
(31.15)^{a}\end{array}$ & $\begin{array}{l}423.18 \\
(36.26)^{b}\end{array}$ & $\begin{array}{l}81.19 \\
(27.54)^{a}\end{array}$ & $\begin{array}{l}94.60 \\
(31.84)^{a b}\end{array}$ & $\begin{array}{l}130.99 \\
(11.81)^{b}\end{array}$ \\
\hline & $\begin{array}{l}\text { SOD (U SOD } \mathrm{mg}^{-1} \\
\text { protein) }\end{array}$ & $\begin{array}{l}6.40 \\
(1.25)^{\mathrm{a}}\end{array}$ & $6.47(0.82)^{a}$ & $\begin{array}{l}10.23 \\
(2.67)^{b}\end{array}$ & $\begin{array}{l}75.45 \\
(9.5)\end{array}$ & $\begin{array}{l}73.76 \\
(28.00)\end{array}$ & $72.45(3.8)$ \\
\hline & $\begin{array}{l}\text { MTLP }\left(\mu \mathrm{g} \mathrm{g}^{-1}\right. \\
\text { tissues) }\end{array}$ & $\begin{array}{l}876.12 \\
(182.23)^{a}\end{array}$ & $\begin{array}{l}1060.02 \\
(211.85)^{\mathrm{b}}\end{array}$ & $\begin{array}{l}1016.82 \\
(130.17)^{a b}\end{array}$ & & & \\
\hline & $\begin{array}{l}\mathrm{LDH} \\
\left(\mathrm{nmol} \mathrm{min} \mathrm{mg}^{-1} \mathrm{mg}^{-1}\right. \\
\text { protein) }\end{array}$ & $\begin{array}{l}20.57 \\
(5.49)\end{array}$ & $18.97(7.14)$ & $\begin{array}{l}23.06 \\
(10.72)\end{array}$ & $\begin{array}{l}552.03 \\
(89.91)\end{array}$ & $\begin{array}{l}514.02 \\
(96.43)\end{array}$ & $\begin{array}{l}569.50 \\
(208.90)\end{array}$ \\
\hline \multirow[t]{2}{*}{ Damages } & $\begin{array}{l}\text { TBARS (nmol } \\
\text { MDA mg }{ }^{-1} \text { protein) }\end{array}$ & $\begin{array}{l}0.52 \\
(0.11)\end{array}$ & $0.50(0.05)$ & $0.53(0.23)$ & $\begin{array}{l}0.76 \\
(0.20)\end{array}$ & $0.77(0.12)$ & $0.90(0.014)$ \\
\hline & $\begin{array}{l}\text { AChE } \\
\left(\mathrm{nmol} \mathrm{min} \mathrm{mg}^{-1} \mathrm{mg}^{-1}\right. \\
\text { protein) }\end{array}$ & $\begin{array}{l}22.36 \\
(6.24)\end{array}$ & $26.37(9.28)$ & $\begin{array}{l}28.49 \\
(10.71)\end{array}$ & $\begin{array}{l}71.33 \\
(14.23)\end{array}$ & $\begin{array}{l}70.26 \\
(17.69)\end{array}$ & $70.14(8.61)$ \\
\hline
\end{tabular}

Table 3. Slopes and determination coefficients of the best-fit regression lines obtained after In transformation of the raw data shown in Fig. 3. Slopes with different superscripts differed significantly at the $95 \%$ level.

\begin{tabular}{|l|l|l|l|}
\hline $\begin{array}{l}\text { Experimental conditions } \\
\text { Control }\end{array}$ & Animals & Slope & Coefficient $R^{2}$ \\
\hline Soluble Cu & S. plana & $-0.0096^{\mathrm{a}}$ & 0.9604 \\
\hline CuO Nanoparticles & S. plana & $-0.0043^{\mathrm{b}}$ & 0.9664 \\
\hline S. plana & $-0.0051^{\mathrm{b}}$ & 0.9318 \\
\hline Control & & & \\
\hline Soluble Cu & N. diversicolor & $-0.1433^{\mathrm{a}}$ & 0.9478 \\
\hline CuO Nanoparticles & N. diversicolor & $-0.0734^{\mathrm{b}}$ & 0.8545 \\
\hline & N. diversicolor & $-0.132^{\mathrm{a}}$ & 0.8299 \\
\hline
\end{tabular}




\section{Figures}

Figure 1. Size distribution (A) of CuO nanoparticles in DIW and evolution of the size of CuO nanoparticles when a drop of sea water ( $t=2$ days) is incorporated in the DIW suspension (B).
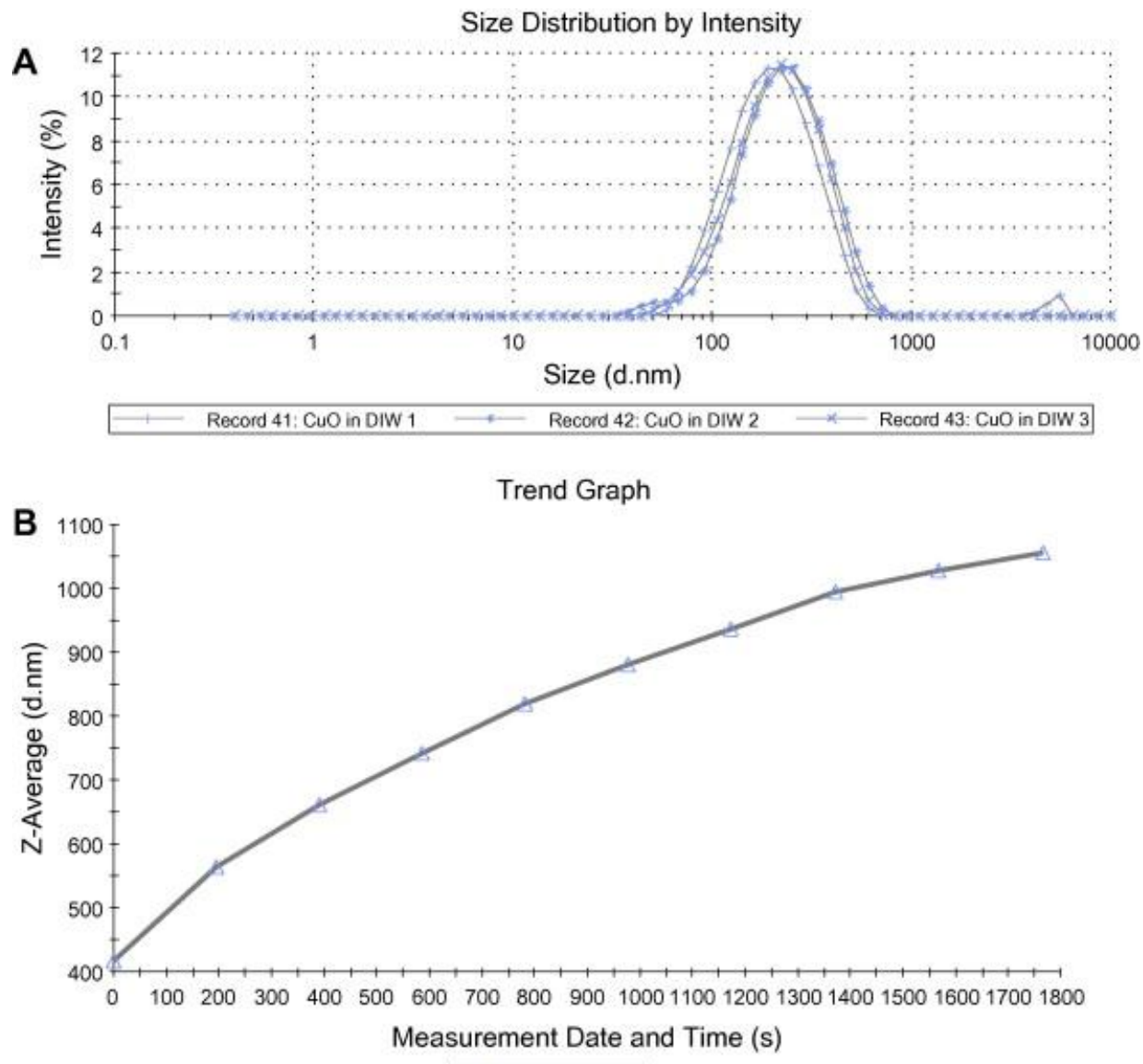

Z-Average 
Figure 2. Mean mass (and standard deviation) of copper accumulated ( $\mu \mathrm{g})$ by DGT units $(n=8)$ during the time of exposure. (A) Control; (B) Soluble Cu; (C) CuO NP.
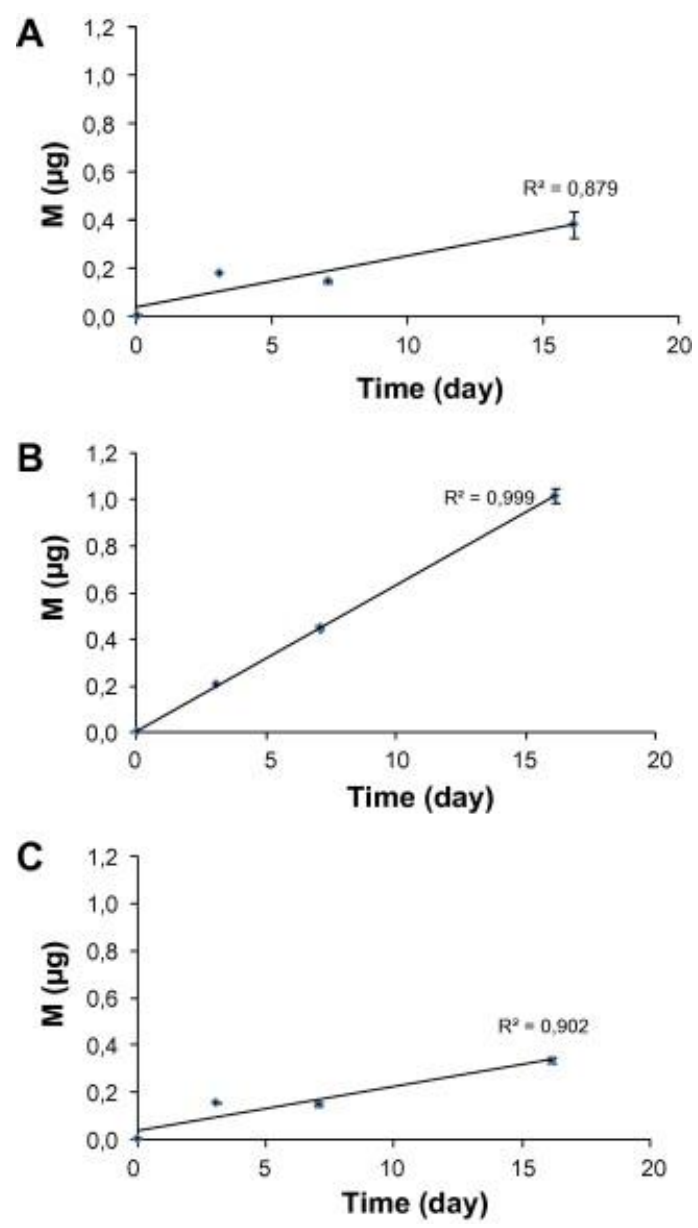

Fig. 3. Percentage of unburrowed clams (A) Scrobicularia plana $(n=20)$ and ragworms (B) Hediste diversicolor $(n=20)$ at different times $(\min )$. Animals were previously exposed to the different experimental conditions: sea water only (control $\bullet$ ), soluble copper $\Delta, \mathrm{CuO}$ nanoparticles $\times$; and allowed to burrow in their sediment of origin (Bay of Bourgneuf).
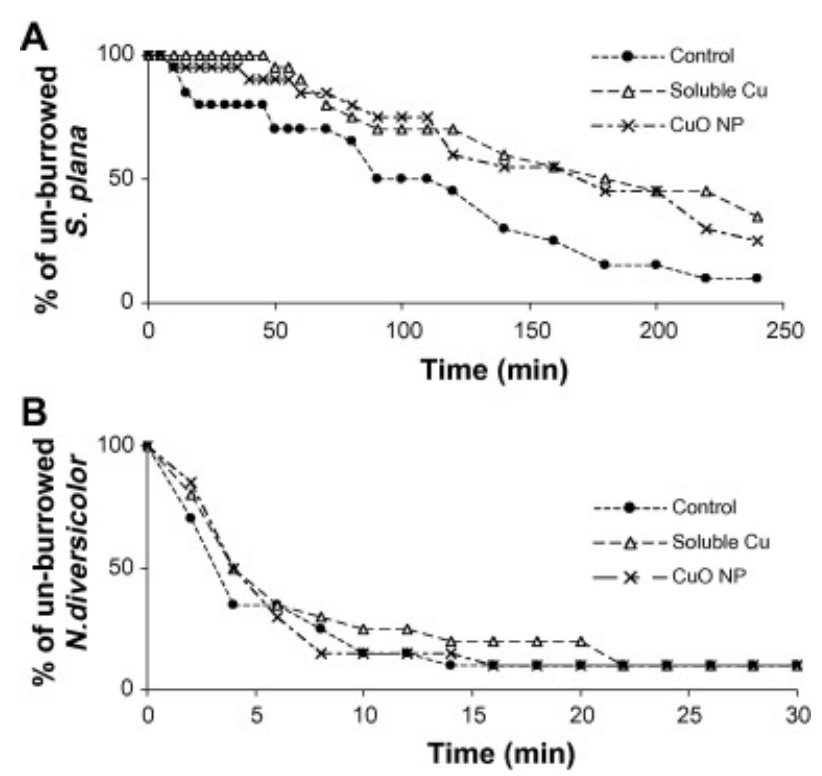